\title{
SECULAR TRENDS OF ACCUMULATION RATE ON ICE CORES FROM DUNDE ICE CAP, CHINA OVER THE LAST 1000 YEARS
}

\author{
(Abstract) \\ by \\ Wu Xiaoling, Li Zhongqin, Xie Zichu
}

(Lanzhou Institute of Glaciology and Geocryology, Academia Sinica, Lanzhou 73000, China)

\begin{abstract}
Cooperative research programs were conducted on the Dunde Ice Cap $\left(38^{\circ} 06^{\prime} \mathrm{N}, 96^{\circ} 26^{\prime} \mathrm{E}\right)$, China, in 1984, 1986, 1987, by the Lanzhou Institute of Glaciology and Geocryology (LIGG), China and the Byrd Polar Research Center (BPRC), U.S.A. This paper gives the preliminary results of the analysis on accumulation rate of the ice cap over the last 1000 years. Three ice cores were recovered to bedrock from the ice-cap summit ( $5324 \mathrm{~m}$ a.s.l.). Core D-1 (139.8 $\mathrm{m}$ long) was divided in the field along the entire length and was shared equally between LIGG and BPRC. Core D-2 (136.6 m long) was returned frozen complete to the LIGG for ice-core measurements. In Core D-3 (138.4 m long) the upper sectors were melted and bottled in the field and the lower sectors were returned frozen to the BPRC, U.S.A. Core D-1 was analyzed in China along the entire length for oxygen isotope, liquid conductivity and $\mathrm{pH}$. A year-by-year dating of the ice cores has been made with Dansgaard-Johnsen's flow pattern by using the data of
\end{abstract}

surface strain-rate (August 1986 to August 1987) and tritium measurements. The resulting time-scales of the ice cores in Dunde Ice Cap yield an age of 4600 yr B.P. The annual layer thicknesses of core D-1 were measured mainly by $\delta^{18} \mathrm{O}$ analysis and liquid conductivity. The lower $\delta^{18} \mathrm{O}$ is generally associated with higher electrical conductivity. Annual layer thickness was converted to accumulation rates and compared with meteorological records from Delingxa Meteorological Station. The mean accumulation rate is $518 \mathrm{~mm}$ in ice-equivalent. Particular attention is given to the possible impact of the Little Ice Age. Based on spectral analysis of time series for the accumulation variation with depth, short-term $(30,33$ year at 0.01 level $)$ and intermediate-term variation (120 year) were discussed. The ice-core research program has been supported by the Chinese National Foundation of Natural Science under Grant DO125-4860011.

\section{SOLUBLE IMPURITIES IN ICE CORE D-1 OF DUNDE ICE CAP, CHINA, OVER THE LAST 500 YEARS}

\author{
(Abstract) \\ by \\ Wu Xiaoling, Liu Jingshou, Yang Qinzhou \\ (Lanzhou Institute of Glaciology and Geocryology, Academia Sinica, Lanzhou 73000, China)
}

\begin{abstract}
This paper gives the preliminary results of 26 trace element measurements of ice cores from Dunde Ice Cap, China. The chemical composition of soluble impurities along ice core D-1 covering the last 500 years B.P., is reported and interpreted in terms of atmospheric contributions. The dust content in ice cores of Dunde Ice Cap is 36 times higher than in Byrd Station, Antarctica. Variations of soluble elements such as $\mathrm{Ca}, \mathrm{Mg}, \mathrm{K}$ and $\mathrm{Na}$, in Dunde Ice cores are very sensitive to climatic and environmental changes. The 25 trace elements in ice core $\mathrm{D}-1(\mathrm{~K}, \mathrm{Na}$, $\mathrm{Ca}, \mathrm{Mg}, \mathrm{Cd}, \mathrm{Cr}, \mathrm{Co}, \mathrm{Cu}, \mathrm{Fe}, \mathrm{Mn}, \mathrm{Mo}, \mathrm{Ni}, \mathrm{Pb}, \mathrm{Al}, \mathrm{Sr}, \mathrm{Ti}$, $\mathrm{V}, \mathrm{Zn}, \mathrm{As}, \mathrm{Ba}, \mathrm{B}, \mathrm{Li}, \mathrm{P}, \mathrm{S}, \mathrm{Sn}$ ) were measured. Cationic ions arranged in order of content are as follows: $\mathrm{Ca}>\mathrm{Na}$ $>\mathrm{Mg}>\mathrm{K}>\mathrm{Al}>\mathrm{Fe}>\mathrm{Zn}>\mathrm{Cu}>\mathrm{Mn}>\mathrm{Pb}>\mathrm{Cr}>\mathrm{Ni}>$
\end{abstract}

$\mathrm{Co}>\mathrm{Cd}$ etc. The content of soluble impurities has typical terrestrial features. Rock-forming elements such as $\mathrm{Ca}, \mathrm{Mg}$, $\mathrm{K}, \mathrm{Na}, \mathrm{Si}, \mathrm{Al}$, and $\mathrm{Fe}$ make up $99 \%$ in the core samples.

Particular attention is given to the possible impact of the so-called "pre-Industrial Revolution period" and man's influence on the atmospheric chemistry. The spectral analysis of time series for the variation of each of the 26 contributions show a 92 year cycle that is present in the variation of all 26 ions with depth. Short-term variations, such as $23,31,48,81$ year cycles, are also discussed. The ice-core research program has been supported by the Chinese National Foundation of Natural Science under Grant DO125-4860011. 